\title{
UJI AKTIVITAS ANTIOKSIDAN EKSTRAK ETANOL PROPOLIS LEBAH TRIGONA (Trigona itama) MENGGUNAKAN METODE DPPH
}

\author{
Isna Wardaniati ${ }^{1)}$ Rahma Yanti $^{2)}$ \\ 1) D III Analis Farmasi dan makanan, FKIK Universitas Abduurab \\ Jl. Riau ujung No 76 Pekanbaru Indonesia \\ email : isna.wardaniati@univrab.ac.id \\ ${ }^{2)}$ D III Analis Farmasi dan makanan, FKIK Universitas Abduurab \\ Jl. Riau ujung No 76 Pekanbaru Indonesia \\ email : rahma.yanti@univrab.ac.id
}

\begin{abstract}
Propolis Trigona itama (PTI) is a natural source getting from bee's collected plants resin. This research aims to determine the antioxidant activity of PTI ethanol extract using DPPH assay method. Ascorbic acid was used as antioxidant standard. The $\mathrm{IC}_{50}$ was measured using micro-plate reader with maximum wavelength of $520 \mathrm{~nm}$. The result showed that PTI ethanol extract has an intermediate antioxidant activity with $\mathrm{IC}_{50}$ value of 105.11 $\mathrm{ppm}$. The activity of sample was lower that standard which was a strong antioxidant with $\mathrm{IC}_{50}$ value of 7.24 ppm.
\end{abstract}

Keywords : antioxidant, propolis, bee, Trigona itama, DPPH

\section{ABSTRAK}

Propolis lebah trigona (Trigona itama) merupakan bahan alami dari resin atau getah berbagai tanaman yang dikumpulkan lebah. Penelitian ini bertujuan untuk mengetahui aktivitas antioksidan ekstrak etanol propolis lebah trigona (Trigona itama). Penentuan aktivitas antioksidan dilakukan menggunakan metode DPPH dengan asam askorbat sebagai pembanding. Alat yang digunakan adalah microplate reader dengan panjang gelombang maksimum pengukuran adalah $520 \mathrm{~nm}$. Parameter yang digunakan untuk mengetahui aktivitas antioksidan adalah IC $_{50}$ (Inhibition Concentration). Berdasarkan penelitian ini, sampel ekstrak etanol propolis lebah trigona (Trigona itama) memiliki nilai $\mathrm{IC}_{50}$ lebih besar dibandingkan asam askorbat sehingga sampel menunjukkan aktivitas antioksidan kategori sedang dengan nilai IC $_{50}$ sampel sebesar $105,11 \mathrm{ppm}$ dan nilai $\mathrm{IC}_{50}$ pembanding sebesar 7,24 ppm sebagai aktivitas antioksidan kategori sangat aktif.

Kata kunci : antioksidan, propolis, lebah, trigona, DPPH

\section{Pendahuluan}

Dewasa ini, dunia kedokteran dan kesehatan banyak membahas tentang radikal bebas dan antioksidan. Radikal bebas merupakan suatu senyawa yang terbentuk di dalam tubuh secara terus menerus melalui proses metabolisme sel normal, peradangan, kekurangan gizi, polusi lingkungan, ultraviolet dan asap rokok (Winarsi, 2007). Berbagai sumber mengatakan bahwa pembentukan radikal bebas dapat dihambat dan dinetralisir oleh antioksidan yang juga bermanfaat bagi kesehatan dan berperan dalam mencegah proses penuaan (Winarsi, 2007: Tapan, 2005).

Komposisi antioksidan terdiri dari antioksidan alami dan antioksidan sintetik (Cahyadi, 2006). Hermanto (2012) mengungkapkan bahwa penggunaan antioksidan alami memiliki tingkat keamanan yang 
baik jika dibandingkan antioksidan sintetik. Penelitian Lotfy (2006) menyimpulkan bahwa salah satu bahan alam yang telah mempertahankan kualitasnya selama periode waktu yang panjang sebagai solusi alami menyembuhkan penyakit dengan berbagai khasiat adalah propolis. Menurut Siregar et al. (2011), komponen utama propolis berasal dari resin atau getah tanaman yang dikumpulkan lebah. Menurut Mahani et al. (2011), salah satu pengujian aktivitas antioksidan adalah metode DPPH dengan menggunakan 1,1difenil-2-pikrilhidrazil (DPPH) sebagai radikal bebas. Dalam penelitian Novilla (2011) menyimpulkan bahwa terdapat aktivitas antioksidan ekstrak etanol propolis sebesar 37,170\% pada lebah penghasil propolis (lebah jenis Apis mellifera) menggunakan metode DPPH, sehingga ekstrak etanol propolis berpotensial untuk dikembangkan pemanfaatannya sebagai antioksidan.

Lebah trigona (Trigona itama) merupakan salah satu jenis lebah yang menghasilkan propolis. Didasarkan pada kajian ilmiah yang telah ditelusuri, belum ada pengujian tentang aktivitas antioksidan yang dikhususkan pada propolis lebah trigona (Trigona itama) sedangkan menurut Mahani et al. (2011), lebah trigona memproduksi propolis lebih tinggi jika dibandingkan dengan jenis lebah penghasil propolis lainnya.

Pengujian aktivitas antioksidan pada penelitian ini menggunakan metode DPPH (1,1-difenil-2pikrilhidrazil) dengan menggunakan microplate reader. Metode DPPH merupakan metode yang sederhana, mudah, dan penggunaan sampelnya dalam jumlah yang sedikit dengan waktu yang singkat (Hanani et al., 2005). Pada penelitian ini, asam askorbat yang dikenal sebagai antioksidan alami digunakan sebagai pembanding terhadap adanya aktivitas antioksidan.

\section{Tinjauan Pustaka}

\subsection{Antioksidan}

Antioksidan merupakan senyawa pemberi elektron (electron donor) atau reduktan. Senyawa ini memiliki berat molekul kecil, tetapi mampu menghambat dan menginaktivasi berkembangnya reaksi oksidasi dengan cara mencegah terbentuknya radikal dan mengikat radikal bebas serta molekul yang sangat reaktif, akibatnya kerusakan sel akan dihambat (Winarsi, 2007).

Kecukupan asupan antioksidan secara optimal diperlukan pada semua kelompok umur. Konsumsi makanan yang mengandung antioksidan dapat meningkatkan status imunologis dan menghambat timbulnya penyakit degeneratif (Winarsi, 2007). Antioksidan terdiri dari antioksidan alami dan antioksidan sintetik. Antioksidan alami diantaranya turunan fenol, kumarin, hidroksi sinamat, tokoferol, difenol, flavonoid, dihidro flavon, katekin, nonfenol, dan asam askorbat. Sedangkan antioksidan sintetik seperti butil hidroksi anisol, butil hidroksi toluen, propil galat, dan etoksikuin (Cahyadi, 2006). Penggunaan antioksidan alami dinilai memiliki tingkat keamanan yang baik jika dibandingkan antioksidan sintetik (Hermanto, 2012).

\subsection{Radikal Bebas}

Radikal bebas merupakan suatu senyawa yang terbentuk di dalam tubuh secara terus menerus melalui proses metabolisme sel normal, peradangan, kekurangan gizi, polusi lingkungan, ultraviolet dan asap rokok. Pembentukan radikal bebas dihubungkan dengan adanya reaksi oksidasi yang berlebihan di dalam tubuh. Reaksi oksidasi merupakan reaksi yang terjadi setiap saat bahkan ketika manusia bernafas. Reaksi ini mencetuskan terbentuknya radikal bebas yang sangat aktif dan dapat merusak struktur serta fungsi sel di dalam tubuh yang merupakan awal dari sebagian besar penyakit (Winarsi, 2007: 11).

Menurut Halliwell dan Guteridge (1991) seperti dikutip Winarsi (2007), senyawa radikal bebas berpotensi merusak basa DNA sehingga mengacaukan sistem info genetika, dan berlanjut pada pembentukan sel kanker. Diplock (1991) seperti dikutip Winarsi (2007) mengungkapkan bahwa kerusakan molekul protein oleh senyawa oksigen reaktif akan menimbulkan penyakit katarak.

Berbagai kemungkinan dapat terjadi akibat kerja radikal bebas. Misalnya gangguan fungsi sel, kerusakan struktur sel, molekul termodifikasi yang tidak dapat dikenali oleh sistem imun, dan bahkan mutasi. Semua bentuk gangguan tersebut dapat memicu munculnya berbagai penyakit. Dengan meningkatnya usia seseorang, pembentukan radikal bebas juga semakin meningkat. Dampak reaktivitas senyawa radikal bebas bermacam-macam mulai dari kerusakan sel atau jaringan, penyakit autoimun, penyakit degeneratif hingga kanker (Sadikin, 2001 dalam Winarsi, 2007).

\subsection{Lebah Trigona}


Lebah trigona merupakan lebah asli Asia yang termasuk kedalam lebah tanpa sengat (Mahani et al., 2011). Lebah trigona di Indonesia memiliki beberapa nama daerah, yaitu klanceng atau lonceng (Jawa), kelulut (Kalimantan), teuweul (Sunda), gala-gala (Sumatera) atau disebut lebah lilin (Sarwono, 2000).

Ukuran lebah trigona yaitu sekitar $3 \mathrm{~mm}-8 \mathrm{~mm}$ dan sangat lincah bergerak karena sepasang sayap yang berukuran lebih panjang dari badannya. Lebah trigona mempunyai 3 pasang kaki yang semuanya beruas-ruas dan sepasang kaki belakang memiliki duri-duri yang sangat banyak. Dibagian kepala terdapat sepasang mata yang sangat lebar, sepasang antena dengan mulut berbentuk moncong panjang. Lebah trigona menghuni ruas-ruas batang bambu kering, batang pohon berlubang, celahcelah batu dan plafon rumah (Kementerian Lingkungan Hidup dan Kehutanan, 2016).

\subsection{Propolis}

Propolis merupakan zat yang dihasilkan oleh lebah untuk melindungi sarangnya dari berbagai ancaman, baik ancaman lingkungan yang tidak menguntungkan ataupun serangan organisme lain. Komponen utama propolis berasal dari resin atau getah berbagai tanaman yang dikumpulkan lebah (Siregar et al., 2011). Salah satu lebah dengan kemampuan memproduksi propolis dalam jumlah besar adalah lebah trigona yaitu menghasilkan propolis sebanyak 5,8 kg/tahun (Kementerian Lingkungan Hidup dan Kehutanan, 2016).

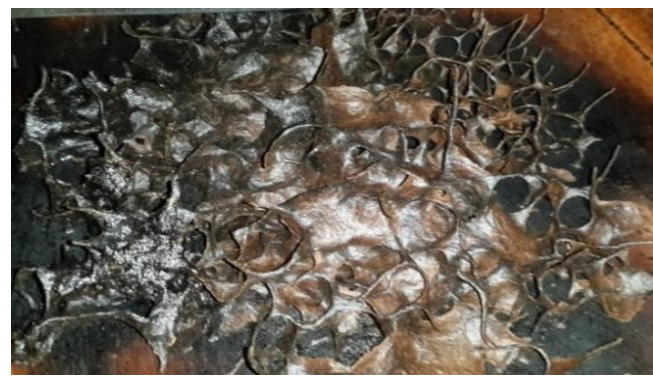

Gambar 1. Propolis lebah trigona (dokumentasi pribadi)

Dalam penelitian Novilla (2011) menyimpulkan bahwa terdapat aktivitas antioksidan pada ekstrak etanol propolis pada lebah penghasil propolis (lebah jenis Apis mellifera) yang potensial untuk dikembangkan pemanfaatannya sebagai antioksidan.

Propolis memiliki variasi warna, aroma, dan kandungan. Kebanyakan propolis berwarna coklat terang sampai gelap, tetapi ada yang berwarna hijau, merah, hitam, kuning, maupun putih. Sifat fisik dan kimia propolis tergantung pada tanaman sumbernya. Propolis dapat berbentuk cair sampai padat. Bentuk ini dipengaruhi oleh temperatur penyimpanan. Semakin tinggi temperatur penyimpanan, propolis akan semakin cair (Siregar et al., 2011).

Pemanfaatan propolis diantaranya dalam dunia kesehatan dan kecantikan, propolis sangat baik untuk kesehatan kulit. Kandungan yang terdapat pada propolis mampu menjaga kulit dari segala macam radikal bebas. Menurut seorang pakar makanan kesehatan dan akunpuntur menyebutkan bahwa propolis dapat menghilangkan jerawat, flek-flek hitam, kerutan dan mengembalikan fungsi kalogen (Siregar et al., 2011). Propolis juga digunakan sebagai terapi penyakit. Sifat utama dari propolis adalah membentuk dan merangsang kekebalan tubuh yang tinggi sehingga segala jenis penyakit dapat diatasi. Penyakit-penyakit yang dapat diobati oleh propolis antara lain diabetes mellitus, radang paru-paru, herpes, bronkitis, wasir dan jantung koroner. Selain penyakit berat, propolis juga dapat menyembuhkan penyakit-penyakit ringan seperti jerawat, bisul, kutil, dan luka bakar.

\section{Metode Penelitian}

\subsection{Alat dan Bahan}

Alat yang digunakan yaitu pinset, beaker glass (Pyrex), timbangan analitik (Boeco Germany), pisau, botol maserasi, gelas ukur (Pyrex), ultrasonic bath (Branson 1510), corong (Pyrex), erlenmeyer (Pyrex), rotary evaporator (Buchi R-14), botol vial, spatula, pipet mikro (Socorex Acura 855 dan Socorex Acura 82), lempeng sumur (Berthold Tristar LB 941), microplate reader (Berthold Tristar LB 941). 
Bahan yang digunakan pada penelitian ini adalah propolis lebah trigona (Trigona itama), etanol 96\% (Emsure), metanol (Emsure), akuades (Brataco), DPPH (Sigma Aldrick), kertas saring (Whatman No 1), asam askorbat (Sigma Aldrick).

\subsection{Prosedur Kerja}

a. Pengambilan propolis

Propolis lebah trigona (Trigona itama) diambil dan dipisahkan dari sarangnya. Propolis dipotong menjadi beberapa bagian kecil. Tiap potongan dikumpulkan dan dilakukan penimbangan.

b. Ekstraksi propolis

Potongan propolis ditimbang, ekstraksi dilakukan dengan cara merendam potongan propolis mentah menggunakan etanol 96\% sampai terendam. Proses ekstraksi dengan cara perendaman dilakukan selama 2-7 hari menggunakan alat pengocokan ultrasonic bath sekitar 60 menit pada tiap hari ke-2 sebelum dilakukan pergantian pelarut. Menurut Effany (2012: 15), filtrat dan ampas hasil ekstraksi dipisahkan dengan cara disaring menggunakan kertas saring Whatman No.1. Semua filtrat hasil ekstraksi dikumpulkan untuk dipekatkan menggunakan rotary evaporator dengan suhu $50^{\circ} \mathrm{C}$ dan kecepatan putaran $60 \mathrm{rpm}$ sampai terbentuk ekstrak kental propolis. Ekstrak kental propolis ditimbang untuk mendapatkan nilai rendemen.

Nilai rendemen $=\frac{\text { berat akhir }}{\text { berat awal }} 100 \%$.

c. Uji DPPH

1. Pembuatan larutan DPPH 80 ppm (Almurdani, 2013) Sebanyak $\pm 2 \mathrm{mg}$ DPPH dilarutkan dengan $2 \mathrm{ml}$ metanol sehingga didapatkan konsentrasi DPPH 1000 ppm. Kemudian dilakukan pengenceran sehingga diperoleh larutan DPPH dengan konsentrasi $80 \mathrm{ppm}$.

2. Pembuatan larutan sampel (Novilla, 2011)

Sebanyak $\pm 2 \mathrm{mg}$ ekstrak propolis dilarutkan dengan $2 \mathrm{ml}$ metanol sehingga diperoleh konsentrasi larutan sampel $1000 \mathrm{ppm}$ (A). Larutan dilakukan pengenceran sehingga diperoleh variasi konsentrasi larutan 500 ppm (B); 250 ppm (C); 125 ppm (D); 62,5 ppm (E); dan 31,25 $\operatorname{ppm}(\mathrm{F})$.

3. Pembuatan larutan pembanding (Novilla, 2011)

Sebanyak $\pm 2 \mathrm{mg}$ asam askorbat dilarutkan dengan $2 \mathrm{ml}$ metanol sehingga diperoleh konsentrasi larutan sampel $100 \mathrm{ppm}$ (A). Larutan dilakukan pengenceran sehingga diperoleh variasi konsentrasi larutan 50 ppm (B); 25 ppm (C); 12,5 ppm (D); 6,25 ppm (E); dan 3,125 ppm (F).

4. Penentuan Aktivitas Antioksidan

Uji aktivitas antioksidan dilakukan menggunakan microplate reader dengan metode DPPH (1,1-Difenil-2-pikrihidrazil). Plate terdiri dari baris A-H masing-masing berjumlah 12 sumur. Sebanyak $50 \mu 1$ metanol dimasukkan ke dalam masing-masing sumur pada baris B sampai pada baris H. Pada baris A dimasukkan sampel sebanyak $100 \mu 1$ dengan konsentrasi 1000 ppm. Sampel pada baris A dipipet sebanyak $50 \mu l$ dan dimasukkan ke baris B sehingga diperoleh sampel dengan konsentrasi $500 \mathrm{ppm}$. Sampel pada baris B dipipet sebanyak $50 \mu \mathrm{l}$ dan dimasukkan ke baris $\mathrm{C}$ sehingga diperoleh sampel dengan konsentrasi $250 \mathrm{ppm}$. Sampel pada baris $\mathrm{C}$ dipipet sebanyak $50 \mu \mathrm{l}$ dan dimasukkan ke baris D sehingga diperoleh sampel dengan konsentrasi $125 \mathrm{ppm}$. Sampel pada baris D dipipet sebanyak $50 \mu \mathrm{l}$ dan dimasukkan ke baris E sehingga diperoleh sampel dengan konsentrasi $62,5 \mathrm{ppm}$. Sampel pada baris E dipipet sebanyak $50 \mu \mathrm{l}$ dan dimasukkan ke baris $\mathrm{F}$ sehingga diperoleh sampel dengan konsentrasi $31,25 \mathrm{ppm}$. Sampel pada baris F dipipet sebanyak $50 \mu 1$ lalu dibuang. Baris A-G ditambahkan DPPH sebanyak $80 \mu 1$ dengan konsentrasi $80 \mathrm{ppm}$. Campuran diinkubasi pada tempat gelap selama 30 menit lalu diukur nilai absorbansinya pada panjang gelombang $520 \mathrm{~nm}$ dengan menggunakan microplate reader. Untuk kontrol negatif digunakan DPPH 80 ppm sebanyak 80 $\mu 1$, sedangkan untuk blanko digunakan metanol absolut sebanyak $50 \mu \mathrm{l}$. Asam askorbat digunakan sebagai kontrol positif dengan perlakuan yang sama seperti perlakuan sampel dengan variasi konsentrasi larutan 100 ppm (A); 50 ppm (B); 25 ppm (C); 12,5 ppm (D); 6,25 ppm (E); dan 3,125 ppm (F) (Almurdani, 2013). 


\subsection{Analisa Data}

Analisa data yang dilakukan pada uji aktivitas antioksidan sampel ditentukan dengan menghitung persentase inhibisi serapan radikal DPPH dan nilai IC $_{50}$ dari persamaan regresi linier.

Perhitungan persentase inhibisi menggunakan rumus:

$\%$ Inhibisi $=\frac{\text { Absorbansi Kontrol-Absorbansi Sampel }}{\text { Absorbansi Kontrol }} 100 \%$

Keterangan :

Absorbansi Kontrol : Serapan radikal DPPH 80 ppm pada panjang gelombang maksimum yang telah diukur sebelumnya.

Absorbansi Sampel : Serapan sampel dalam radikal bebas DPPH 80 ppm pada panjang gelombang maksimum yang telah diukur sebelumnya.

Setelah dihitung persen inhibisi kemudian dihitung nilai $\mathrm{IC}_{50}$ dari persamaan regresi linier $\mathrm{Y}=\mathrm{B}$. Ln $\mathrm{X}+\mathrm{A}$ dengan $(\mathrm{X})$ sebagai konsentrasi sampel dan (Y) adalah persen aktivitas antioksidan (Suryawati et al., 2013).

Aktivitas antioksidan diukur sebagai hasil penurunan serapan larutan DPPH karena adanya penambahan sampel. Aktivitas antioksidan diukur dengan menghitung jumlah pengurangan intensitas warna ungu DPPH yang sebanding dengan pengurangan konsentrasi larutan DPPH yang didefenisikan sebagai konsentrasi senyawa antioksidan yang menyebabkan hilangnya 50\% aktivitas DPPH (Molyneux, 2004).

\section{Hasil dan Pembahasan}

Secara organoleptis sampel propolis lebah trigona berwarna coklat kehitaman, tidak berasa, berbau khas aromatik, dan mudah lengket.

1. Nilai rendemen ekstrak yang diperoleh adalah $35,64 \%$ dari $33,78 \mathrm{~g}$ propolis.

2. Persen inhibisi dari ekstrak etanol propolis lebah trigona (Trigona itama) pada konsentrasi $1000 \mathrm{ppm}$; $500 \mathrm{ppm} ; 250 \mathrm{ppm} ; 125 \mathrm{ppm} ; 62,5 \mathrm{ppm}$ dan $31,25 \mathrm{ppm}$, masing masing adalah 80,23\%; 73,78\%; $61,84 \% ; 52,64 \% ; 43,25 \%$ dan $31,90 \%$.

3. Persen inhibisi dari pembanding (asam askorbat) pada konsentrasi $100 \mathrm{ppm} ; 50 \mathrm{ppm} ; 25 \mathrm{ppm} ; 12,5$ ppm; 6,25 ppm dan 3,125 ppm, masing masing adalah $98,81 \% ; 83,79 \% ; 72,33 \% ; 60,47 \% ; 48,62 \%$ dan $33,60 \%$.

4. Persamaan regresi linier ekstrak etanol propolis lebah trigona (Trigona itama) adalah $\mathrm{Y}=14,12$. Ln $\mathrm{X}-$ 15,73 dengan $r=0,99$ dan menghasilkan nilai IC $_{50}$ sebesar 105,11 ppm.

5. Persamaan regresi linier asam askorbat adalah $\mathrm{Y}=18,28$. Ln $\mathrm{X}+13,81$ dengan $\mathrm{r}=0,99$ dan menghasilkan nilai $\mathrm{IC}_{50}$ sebesar 7,24 ppm.

\section{Pembahasan}

Penelitian uji aktivitas antioksidan ekstrak etanol propolis lebah trigona (Trigona itama) merupakan penelitian deskriptif dengan uji kuantitatif metode serapan radikal DPPH (1,1-difenil-2pikrilhidrazil) menggunakan microplate reader. Selain metode DPPH, menurut Prakash et al (2001: 1), aktivitas antioksidan dapat diukur dengan berbagai metode seperti metode anion superoksida $\left(\mathrm{O}_{2}\right)$, metode hidroksi $(\mathrm{OH})$ atau metode peroksida, metode TBARS, ABTS, dan metode ORAC namun metode DPPH memiliki keuntungan diantaranya merupakan metode yang tidak menggunakan waktu yang lama, sederhana dan lebih murah.

Penelitian ini diawali dengan adanya proses pengambilan sampel propolis lebah trigona jenis itama yang berwarna coklat kehitaman, tidak berasa, berbau khas aromatik dan mudah lengket. Berdasarkan warna yang dihasilkan, propolis lebah trigona (Trigona itama) memiliki sifat umum seperti propolis jenis lainnya yaitu menurut Siregar et al. (2011), kebanyakan propolis berwarna coklat terang sampai gelap. Sedangkan dilihat dari bentuk yaitu mudah lengket maka karakteristik propolis lebah trigona (Trigona itama) yang dihasilkan berasal dari temperatur $25-45^{\circ} \mathrm{C}$.

Proses ekstraksi lebah trigona (Trigona itama) dilakukan menggunakan pelarut etanol $96 \%$, pemilihan pelarut berdasarkan polaritas pelarut sesuai dengan polaritas propolis, pelarut mudah diuapkan dan dipisahkan, suhu penguapan dan pemisahan tidak merusak propolis dan kedap udara untuk 
menghindari kerusakan akibat oksidasi (Mahani et al., 2011: 24). Selain itu, propolis yang dihasilkan dari pelarut seperti etanol akan bermutu baik serta rendah resiko propolis rusak akibat suhu panas (Mahani et al. (2011). Proses penyarian propolis lebah trigona (Trigona itama) digunakan teknik maserasi dengan cara perendaman selama 2-7 hari terhadap sampel yang dipotong menjadi beberapa bagian kecil dan ditambah pengocokan menggunakan alat pengocokan modern yaitu ultrasonic bath sekitar 60 menit dengan kecepatan putaran $50 \mathrm{rpm}$ pada tiap hari ke-2 sebelum dilakukan pergantian pelarut. Proses penyarian ini dilakukan ditempat yang terlindung dari cahaya untuk mencegah kemungkinan terjadinya kerusakan sebagian senyawa yang kurang stabil terhadap cahaya.

Pemilihan teknik maserasi karena teknik maserasi merupakan teknik ekstraksi yang dilakukan untuk bahan yang tidak tahan panas dan teknik maserasi sangat cocok untuk ekstraksi propolis yang tidak tahan pada suhu tinggi (Anggraini, 2006). Adapun fungsi pengocokan terhadap sampel yang dipotong menjadi bagian kecil adalah untuk mempermudah pelarut masuk kedalam sel propolis sehingga mempercepat penarikan zat aktif dari dalam sel dan mempermudah proses pemisahan zat aktif untuk menghasilkan proses ekstraksi yang sempurna, sedangkan proses pengocokan modern menggunakan alat ultrasonic bath untuk meningkatkan kelarutan dan jumlah rendemen kasar dalam waktu yang singkat dengan tidak menggunakan banyak pelarut sehingga pemisahan tidak merusak propolis dan kedap udara untuk menghindari kerusakan akibat oksidasi. Sebagaimana prinsip alat ultrasonic bath yaitu didasarkan oleh adanya pergerakan getaran gelombang ultrasonik (frekuensi $>16-20 \mathrm{kHz}$ ) yang dihantar dari suatu media ke media lain yang saling bersentuhan secara terus menerus antara satu sama lain dalam waktu yang ditentukan untuk meningkatkan kelarutan suatu hasil sarian. Menurut Zou et al. (2014), ultrasonik juga dapat menurunkan suhu operasi pada ekstrak yang tidak tahan panas, sehingga cocok diterapkan pada ekstraksi senyawa bioaktif yang tidak tahan panas.

Filtrat hasil proses maserasi dilakukan pemekatan untuk penguapan pelarut sehingga didapatkan ekstrak pekat propolis hasil ekstraksi yang dipisahkan dengan cara disaring menggunakan kertas saring Whatman No.1. Penggunaan penyaringan dalam proses ini adalah untuk memisahkan pengotor dan kontaminan yang tidak diinginkan berada didalam hasil ekstraksi. Proses penguapan pelarut dilakukan menggunakan rotary evaporator dengan suhu $50^{\circ} \mathrm{C}$ dan kecepatan putaran $60 \mathrm{rpm}$ sampai terbentuk ekstrak pekat propolis. Penggunaan suhu $50^{\circ} \mathrm{C}$ pada proses penguapan etanol relatif mudah dan singkat karena pada suhu tersebut etanol berada dalam kondisi vakum sehingga etanol sangat mudah menguap (Mahani et al., 2011). Proses itu berhubungan dengan prinsip kerja rotary evaporator yaitu adanya proses penguapan pelarut dibawah titik didih, seperti titik didih etanol berkisar antara $60^{\circ} \mathrm{C}-78^{\circ} \mathrm{C}$ (Kementerian Kesehatan Republik Indonesia, 2014). Proses penguapan dibawah titik didih yaitu $<60^{\circ} \mathrm{C}$ karena adanya tekanan yang menyebabkan uap pelarut mengembun dan akhirnya jatuh ke tabung penampung sehingga senyawa yang dipisahkan dari pelarut etanol tidak rusak oleh suhu tinggi maka didapatkan nilai rendemen ekstrak pekat propolis lebah trigona jenis itama hasil ekstraksi menggunakan pelarut etanol 96\% sebesar 35,64\% terhadap $33,78 \mathrm{~g}$ propolis. Adapun hal yang mempengaruhi nilai rendemen adalah pelarut yang digunakan dan proses ekstraksi sampel.

Aktivitas antioksidan diuji menggunakan metode DPPH dengan menghitung nilai $\mathrm{IC}_{50}$. Metode DPPH diuji menggunakan alat microplate reader yaitu suatu spektrofotometer khusus yang disusun untuk membaca lempeng mikro (microplate) dengan kemudahan pengujian yang tidak menggunakan jumlah sampel yang banyak dalam waktu yang singkat. Adapun prinsip kerja microplate reader menurut World Health Organization (2008), yaitu microplate reader memiliki suatu sistem deteksi yang mendeteksi cahaya yang berasal dari sampel, menguatkan sinyal dan menentukan absorbansi sampel. Selanjutnya suatu sistem pembacaan mengubahnya menjadi data yang memungkinkan interpretasi hasil pengujian. Pengujian aktivitas antioksidan berhubungan dengan persamaan regresi yang dibuat dalam bentuk kurva hubungan antara konsentrasi sampel dan aktivitas antioksidan yang dinyatakan dalam persen inhibisi. Konsentrasi sampel propolis lebah trigona jenis itama terdiri dari variasi konsentrasi sampel 1000 ppm; 500 ppm; 250 ppm; 125 ppm; 62,5 ppm dan 31,25 ppm yang diubah dalam bentuk konsentrasi Ln (Logaritma natural) karena jarak antara masing-masing konsentrasi cukup jauh sehingga apabila tidak diubah dalam bentuk Ln (Logaritma natural) maka akan mempengaruhi persamaan regresi yang dihasilkan dan berhubungan dengan tingkat ketelitian suatu pengujian yang dinyatakan dalam nilai regresi dengan syarat mendekati 1 .

Nilai IC $_{50}$ didefenisikan sebagai konsentrasi senyawa antioksidan yang menyebabkan hilangnya 50\% aktivitas DPPH (1,1-difenil-2-pikrilhidrazil) (Molyneux, 2004). Ekstrak etanol propolis lebah trigona (Trigona itama) pada konsentrasi 105,11 ppm mampu menghambat aktivitas radikal DPPH sebesar 50\%. Menurut Zuhra et al. (2008), aktivitas antioksidan diukur dengan menghitung jumlah pengurangan 
intensitas warna ungu DPPH yang sebanding dengan pengurangan konsentrasi larutan DPPH. Peredaman warna ungu DPPH terjadi akibat adanya senyawa yang dapat memberikan radikal hidrogen kepada radikal DPPH sehingga tereduksi menjadi DPPH-H dan menyebabkan terjadinya peluruhan warna DPPH dari ungu ke kuning. Adapun peredaman warna ungu DPPH pada sampel propolis lebah trigona jenis itama dihasilkan pada sampel dengan konsentrasi 1000 ppm; 500 ppm; 250 ppm; dan 125 ppm dengan \% inhibisi masing-masing $80,23 \% ; 73,78 \% ; 61,847 \%$; dan 52,64\% pada panjang gelombang $520 \mathrm{~nm}$.

Berdasarkan pengujian aktivitas antioksidan ekstrak etanol propolis lebah trigona (Trigona itama) menggunakan metode DPPH menghasilkan nilai IC $_{50}=105,11$ ppm terhadap sampel dengan konsentrasi 1000 ppm; 500 ppm; 250 ppm; 125 ppm; 62,5 ppm dan 31,25 ppm dimana dengan nilai IC $_{50}$ yang dihasilkan menyatakan bahwa propolis lebah trigona (Trigona itama) memiliki aktivitas antioksidan kategori sedang. Adapun nilai $\mathrm{IC}_{50}$ yang dihasilkan dari pembanding asam askorbat yaitu 7,24 ppm. Menurut Jun et al. (2003) dalam Suryawati et al. (2013), senyawa dikatakan sangat aktif sebagai antioksidan jika memiliki nilai $\mathrm{IC}_{50}<50 \mathrm{ppm}$, aktif dengan nilai $\mathrm{IC}_{50}=50-100 \mathrm{ppm}$, sedang dengan nilai IC $_{50}=101-250 \mathrm{ppm}$ dan lemah dengan nilai $\mathrm{IC}_{50}=250-500 \mathrm{ppm}$ dan tidak aktif sebagai antioksidan jika nilai $\mathrm{IC}_{50}>500 \mathrm{ppm}$. Aktivitas antioksidan ekstrak etanol propolis lebah trigona (Trigona itama) berada pada kategori senyawa antioksidan sedang dan aktivitas antioksidan asam askorbat sebagai pembanding berada pada kategori senyawa antioksidan sangat aktif.

\section{Kesimpulan}

Berdasarkan penelitian ini, sampel ekstrak etanol propolis lebah trigona (Trigona itama) memiliki nilai $\mathrm{IC}_{50}$ lebih besar dibandingkan asam askorbat sehingga sampel menunjukkan aktivitas antioksidan kategori sedang dengan nilai $\mathrm{IC}_{50}$ sampel sebesar $105,11 \mathrm{ppm}$ dan nilai $\mathrm{IC}_{50}$ pembanding sebesar 7,24 ppm sebagai aktivitas antioksidan kategori sangat aktif.

\section{REFERENSI}

Almurdani, M., Christine Jose, dan Hilwan Yuda Teruna. 2013. Uji Aktivitas Antioksidan dan Toksisitas Ekstrak Akar Tanaman Amaranthus spinosus. Jurnal Program Studi Kimia. Volume 4

Anggraini, A.D. 2006. Potensi Propolis Lebah Madu Trigona Sp Sebagai Bahan Antibakteri. Bogor: Departemen Biokimia. Fakultas Matematika dan Ilmu Pengetahuan Alam IPB

Cahyadi, W. 2006. Analisis Dan Aspek Kesehatan Bahan Tambahan Pangan. Jakarta: Bumi Aksara

Hanani, E., Mun'im, Abdul, Sekarini R. 2005. Identifikasi Senyawa Antioksidan Dalam Spons Callyspongia Sp Dari Kepulauan Seribu. Majalah Ilmu Kefarmasian, Volume 2(3) Departemen Farmasi FMIPA UI: $127-133$

Hermanto, N. 2012. Daun Sukun Si Daun Ajaib Penakluk Aneka Penyakit. Jakarta: AgroMedia Pustaka

Kementerian Kesehatan Republik Indonesia. 2014. Farmakope Indonesia, Edisi V. Jakarta

Kementerian Lingkungan Hidup dan Kehutanan. 2016. Bahan Ajar Alih Teknologi Lebah Madu. Kuok

Lotfy, M. 2006. Biological Activity Of Bee Propolis In Health And Disease. Asian Pacific Journal of Cancer Prevention. Volume 7: 22-31

Mahani, R. A. Karim dan Nunung N. 2011. Keajaiban Propolis Trigona. Jakarta: Pustaka Bunda

Molyneux, P. 2004. The Use Of The Stable Free Radical Diphenylpicrylhydrazyl (DPPH) For Estimeting Antioxidant Activity. Songklanakarin J. Sci. Technol. 26(2): 211-219

Novilla, A. 2011. Aktivitas Antioksidan Ekstrak Propolis Lebah Madu Lokal (Apis mellifera). Jurnal Kesehatan Kartika. STIKES A. Yani Cimahi: 64-72 
Sarwono, B. 2000. Kiat Mengatasi Permasalahan Praktis Lebah Madu. Jakarta: AgroMedia Pustaka

Siregar, H.C.H., Asnath M.F., dan Yuke O. 2011. Propolis Madu Multikhasiat. Jakarta: Penebar Swadaya Grup.

Suryawati, Frengki, dan Hijra N.S. 2013. The Potential Antioxidant Activity Of Ethanolic Extract Of Aceh Ant-plant (Mymercodia sp) On The Free Radical DPPH (1,1-Diphenyl-2-Pikrilhidrazil). The Third Annual International Conference Syiah Kuala University (AIC Unsyiah) and The Second International Conference on Multidiciplinary Research (ICMR). Faculty of Medicine Syiah Kuala University and Faculty of Veterinary Medicine Syiah Kuala University: 301-305

Tapan, E. 2005. Kanker, Antioksidan \& Terapi Komplementer. Jakarta: Elex Media Komputindo

Winarsi, H. 2007. Antioksidan Alami Dan Radikal Bebas. Yogyakarta: Kanisius

World Health Organization (2008). Maintenance Manual For Laboratory Equipment ( $2^{\text {nd }} e d$.). Geneva, Switzerland: WHO Press.

Zou, T.B., En-Qin Xia, Tai-Ping He, et al. 2014. Ultrasound-Assisted Extraction Of Mangeferin From Mango Leaves Using Response Surface Methodology. Molecules 19. 1411-1421

Zuhra, C.F., Juliarti BT, Herlince S. 2008. Aktivitas Antioksidan Senyawa Flavonoid Dari Daun Katuk (Sauropus androgynous (L.) Merr). Jurnal Biologi Sumatera, Volume 3(1): 7-10 